\title{
Empty Air: \\ Ezra Pound's World War Two Radio \\ Broadcasts
}

Gibran van Ert

ABSTRACT: This essay draws on biographical material and radio transcripts to tell the story of Ezra Pound's collaboration with Italy during the Second World War. It pulls together the numerous and inaccessible broadcasts to provide an overview of the central themesand important omissions-of the American poet's foray in to broadcasting. Pound's collaboration, it is argued, was more an expression of his own personality than an act of Italian psychological warfare. The essay highlights a curious chapter in the history of propaganda, contributes to the study of anti-Semitism, and provides for literary scholars an insight into the later thought of one of the most important figures in modern literature.

Ezra Pound was one of the greatest poets of the twentiech century. Apart from his own works, which include Hugh Selwyn Mauberley, Homage to Sextus Propertius, and the Cantos, the criticism, advice, and guidance he offered writers such as Hemingway, Elior, and Yeats makes him a pivotal figure in twentiech-century English-language literature. Referred to as il miglior fabbro (the best craftsman) in the dedication to The Waste Land. Pound extensively edited Eliot's most famous work, arguably rendering it the masterpiece it is. 'In this and many other instances, Pound's influence on the literature of his time is pervasive. Critic Hugh Kenner goes as far as to dub the modern period of English literature the Pound Era. ${ }^{2}$

One of the ideas Pound shared with many of his literary contemporaries in the inter-war period was a dissatisfaction with democratic, egalitarian society. In Mauberley, published in 1920, he refers to the "old bitch gone in the teeth" that is this "botched civilisation." Similar expressions of his contempt for democracy are found throughour his vast writings. Soviet Russia's revolutionary 
regime offered no alternative (for Pound, at least), but in 1922 a new social order arose in Fascist Italy. Here was a society and a government that had the "teeth" Pound sought: Mussolini's strength of will combined with Italy's history of artistic achievement. Pound, an American expatriate living in England since 1908, moved to Rapallo in 1925 and there began a remarkable relationship with Fascism that would continue until American occupation forces arrested him for treason in 1945. Between 21 January 1941 and 26 July 1943 Pound wrote and read broadcasts on Rome Radio to be transmitted by short wave to Britain and North America. Along with Lord Haw-Haw, Tokyo Rose, and Axis Sally, Pound joined the ranks of Axis radio propagandists.

But Ezra Pound's collaboration with the Axis differs greatly from that of the more famous Axis radio figures. Unlike the work of Lord Haw-Haw and his ilk, Pound's broadcasts were not carefully orchestrated acts of propaganda; rather, Pound's radio speeches amounted to a curious but oft-forgotten side show to the greater Itralian propaganda effort. Although nominally engaged in a campaign of psychological warfare conducced by the Fascist regime, Pound brought to his broadcasts an intensely personal agenda that coincided with the Fascist line only in its main theme: the hero worship of Mussolini. Pound, who took on no pseudonym for his broadcasts, was largely ignored by Italian officials once they were assured that he was "a friend of Italy." Given this free rein, he used his radio time to discuss subjects of interest to him personally but which bear little resemblance to standard Fascist doctrine. Pound's digressions and irrelevancies were tolerated because, ultimately, he always returned to the theme that both he and the Italian authorities could agree upon: that Mussolini represented an Italian off-shoot of what was best in the American political tradition, and that the world needed to be made aware of his grearness. 
The literature on Ezra Pound is immense. He constitutes an entire industry, both for literary critics and biographers. In spite of Pound's enduring popularity as a subject of study, documentation of his collaboration with Rome Radio is not always satisfying. Most of the broadcasts themselves were recorded by the Americans during the war, and those recordings now reside in the Library of Congress. The surviving original manuscripts of the broadcasts were published in 1978, together with the United States Federal Communications Commission transcriptions of broadcasts, whose manuscripts we do not have, under the title "Ezra Pound Speaking" Radio Speeches of World War Two. Leonard W. Doob, one of Pound's trustees, edited the volume with the assistance of Pound's daughter Mary de Rachewilu. Besides the broadcasts, there exists a large collection of Pound's papers at the Beinecke Library at Yale University. These archives have been studied by Doob and Pound biographers for information about the broadcasts, but gaps in our knowledge remain. Doob suggests that his work with the Italian archives was fruitless, but Tim Redman has since extracted more information from them, and they may yet offer some insights into the poet's work with Ente Italiano Audizione Radio, the Italian broadcasting service. ${ }^{3}$

Secondary source material on Pound is daunting, especially for the historian. Beatrice Ricks' Ezra Pound: $A$ Bibliography of Secondary Works is a good starting place. The work needs updaring as the most recent edition was published in 1986. Ricks begins the bibliography with a nore making direct reference to Pound's Fascist links. Clearly, it was compiled to assist historians and others interested in this aspect of Pound's career, but most of Pound scholarship focuses on his poetry. Most of the biographies and other secondary sources do not remark upon just how bizarre Pound's alliance with Rome Radio was from an ideological and historical perspective. The result is that discussions of Pound's collaboration with Italy tend to consist of superficial 
narratives, frequently coupled with tedious and at worst banal moralising over the significance of the poet's antiSemitism to his art. The best (or rather, worst) example of this is Robert Casillo's 1988 study, The Genealogy of Demons: Anti-Semitism, Fascism, and the Myths of Ezra Pound. Even the most interdisciplinary of historians will find this work jargon-ridden and difficult to follow. Denis Donoghue put it best in his review for The New York Review of Books, when he described Casillo as "disabled by his vocabulary. Logocentric, phallocentric, solar: these are swearwords, hopeless for thinking with; they imprison in stereorypes anyone-even Jacques Derrida-who resorts to them." Similarly, Alan Durant's 1981 Ezra Pound: Identity in Crisis is an example of one of the many secondary works that promise an analysis of Pound's Fascist connection, only to veer off into discussions of a critical and theoretical nature. Durant is not nearly so obscure, and his work may be useful for students of Pound's verse, but it does not fulfil its promise to address fascism-at least not in a manner useful for historians. Of the many biographies, C. David Heymann's Ezra Pound: the Last Rower casts itself as "a political profile" but is not any more interesting or useful on the subject of Pound's Italian connection than the two best biographies, by Noel Stock and Humphrey Carpenter. Stock's 1970 Life of Ezra Pound suffers the limitations of being written during the poet's lifetime and only with the approval of his wife. Carpenter's 1988 biography $A$ Serious Character: the Life of Ezra Pound is the most recent and engaging of the biographies. Three studies of Pound's politics are of note. Wendy Stallard Flory's The American Ezra Pound contains the thoughtful essay, "The Antisemitism of the Rome Radio Broadcasts." Flory notes the discrepancy between Pound's anti-Semitism and the actual policy of Fascist Italy prior to the German takeover. She also observes Pound's ambiguity towards Jews, an ambiguity ignored by Casillo and others. The subjects dealt with in William M. Chace's The Political Identities of Ezra Pound and T.S. Eliot have been explored at greater length elsewhere since the book's publication (1973), but 
that fact only makes his chapter on Pound and Mussolini more admirable for its concision and brevity. All in all, Tim Redman's 1991 Ezra Pound and Italian Fascism is the most exhaustive and satisfying study of Pound's collaboration. Redman is sometimes guilty of being too sympathetic to his subject, but Pound's commentators almost inevitably fall into an attack or a defence of the man.

Perhaps the main reason the literature on Pound is so great is that he himself was such a prolific writer. He wrote pamphlets and articles with startling frequency, on greatly varied topics. The most relevant of his writings for our purposes are Jefferson and/or Mussolini (1935) and L'America, Roosevelt e le Cause della Guerra Presente (1944). Those interested in his economic theories should see Social Credit. an Impact (1935) and, for a challenge, his $A B C$ of Economics

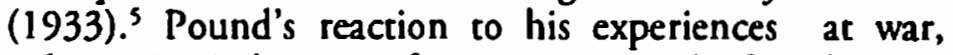
culminating in his arrest for treason, are to be found in one of the century's most celebrated (and controversial) collection of poems, The Pisan Cantos (1948).

Pound's interest in Fascism was not a factor in his 1925 move to Rapallo, but it indicates that he had no strong objections to Mussolini's régime. In late 1926 he wrote to a friend, "I personally think extremely well of Mussolini. If one compares him to American presidents (the last three) or British premiers, etc., in fact one can NOT without insulting him." Although this endorsement is nothing like those he would give in later years, it reveals Pound's tendency to compare Mussolini to American leaders, a tendency that would result in his first important public statement of admiration, Jefferson and/or Mussolini. In an interview with Pound published in the magazine Belvedere in March 1931, he was asked which American he would compare to Mussolini:

Comparisons of this kind are not easy. I will only say that the American historical character who comes to mind when I consider the part of 
Mussolini's effective programme which includes land reclamation, the "battle for grain," and the mobilisation of the nation's internal credit is Thomas Jefferson ....'

In 1932 Pound made flattering comments about 11 Duce to a correspondent, but prefaced them with the warning that they were not to be cited publicly. ${ }^{8} \mathrm{He}$ was as yet not willing to give Mussolini open support.

Later that year Pound tried to gain an audience with the leader, presumably to size him up in person. He asked Mussolini's private secretary for an interview on the weak pretext of discussing "working conditions in the sulphur mines of Sicily" and "the productivity of the cork industry." Predictably, the secretary refused his request. Later, when working on the script of a film on Fascism (never made), he was granted an incerview, which took place on 30 January 1933. ' Pound presented Mussolini a copy of $A$ Draft of XXX Cantos, spoke about C. H. Douglas's Social Credit theory, and seems to have been warmly received. News of the meeting made front page of the Rapallo newspaper, ${ }^{10}$ but no clear account of it exists.

Even without such an account it is certain that Pound's idealisation of Mussolini begins here. Days later, the poet began his earliest English statement of admiration of the Mussolini régime. Jefferson and/or Mussolini was an attempt to prove that "the fundamental likenesses between these two men are probably greater than their differences." "That attempt was largely a failure, as is perhaps demonstrated by the fact that forty different publishers refused the book before it was finally published in 1935. ${ }^{12}$ Pound, in Jefferson and/or Mussolini was more concerned with convincing Britons and Americans that Fascism was a positive development than he was with substantiating his claim that Jefferson and Mussolini were kindred spirits. The two men's similarity was, in Pound's opinion, that both possessed "the will toward order" through which to realize the new societies they envisioned. Pound saw in this principle of order an impulse 
shared by the artist; he continued to refer to II Duce as an artist in later years, perhaps as a way of rationalising his newfound hero's status as a dictator. Seen as an artist, Mussolini gained the artistic license to do as he liked. ${ }^{13}$ Jefferson and/or Mussolini is very unconvincing, but the point is clear enough: both are great men, one following in the tradition of greatness of the other. As Chace remarks, "politics for Pound was ... a kind of hero-worship." 14

Pound did not see this hero-worship of Mussolini, before, during, or after the war, as conflicting in any way with his loyalty to America; on the contrary, in Jefferson and/ or Mussolini and many of his other writings Pound sought to integrate Mussolini into what he perceived to be the greatest American political traditions. "The heritage of Jefferson, Quincy Adams, old John Adams, Jackson, Van Buren is HERE, NOW, in the Italian Peninsulaat the beginning of fascist second decennio," he wrote. ${ }^{15}$ "This is not to say that I 'advocate' fascism in and for America, or that I think fascism is possible in America without Mussolini," "What he ... advocate[d]," writes Chace, was "a renewal of the American promise as set forth by Jefferson. ${ }^{\text {"17 }}$ Pound always located his admiration of Mussolini within the context of his status as an American citizen-a fact which Pound apologists are always quick to bring up.

By 1934 Pound had committed himself to the Fascist régime and to Mussolini himself. The extent of his hero worship is revealed in Canto XLI, published in 1934 in Eleven New Cantos. The canto records, in fragmentary fashion, the January 1933 meeting. Having looked through Pound's XXX Cantos Mussolini pronounces upon them a trivial judgment:

$$
\begin{aligned}
& \text { "MA QVESTO," } \\
& \text { said the Boss, "è divertente." }
\end{aligned}
$$

The meaning of these lines is "But this is amusing." Rather than dismissing the comment, Pound finds in it Mussolini's "capacity to pick out the element of immediate and major 
importance in any tangle"18 that he celebrates in Jefferson and/or Mussolini. "The Boss," he says, was "carching the point before the aesthetes had got there." It is difficult to believe that "the point" of Pound's lifelong work is mere amusement. But the Boss could do no wrong.

When the war broke out Pound began to advocate American neutrality. He began a letter-writing campaign, declaring the war to be a result of "international usury" and Britain's withholding of formerly-German mandated territories. ${ }^{19}$ In November 1939 he suggested that the Italian Government undertake a series of publications with the aim of provoking American sympathy for Fascism. Luigi Villari, of the Institure for Overseas Cultural Relations, refused the idea, which he saw as meddling in the domestic affairs of a country towards which Italy was not hostile. Villari summed Pound up remarkably in an internal memorandum:
Mr Pound ... is a gifted and cultured man with excellent impulses towards us, but is a dreamer who also wants to be involved in economic and financial matters about which he has sume pretty fantastic notions. In the United States, Pound is appreciated as a poet, but as a political and economic writer he is not taken seriously, so that an initiative originating from him would not carry much weight. ${ }^{20}$

But Pound would not be dissuaded and now turned to radio broadcasting as an alternative method. He had recently been given a radio by friends and although he called it the "devil's box" and felt "a double sense of the blessedness of silence when the damn thing is turned off," he was intrigued by the possibilities it offered. ${ }^{21}$ He travelled to Rome and there suggested to Alessandro Pavolini, Minister of Popular Culture and head of the I calian propaganda effort, a radio programme along the same lines as the publications he had suggested to 
Villari. The response, in Pound's words, was: "Well the Ministro looked at me careful and said in perlite words to the effect that: ' $\mathrm{Ez}$... if you think you can use oUR air to monkey in America's INTERNAL politics, you got another one comin."'22

Undaunted, Pound called on employees and representatives of the Ministry of Popular Culture throughout 1940 to encourage its Radio Department to direct propaganda broadcasts to the US propounding the merits of Italian Fascism. He continued to be refused until Italy went to war. At that time the Radio Department, which was now engaged in propaganda broadcasts anyway, began verting him. He was subsequently employed on "The American Hour," a programme heard on short-wave in Britain, the USA, the Pacific, and much of Europe. At first, near the end of the year, he was invited only to send scripts for others to read. But in January he recorded his first broadcast.

The speeches were seven to ten minutes long, and usually two were broadcast per week. Pound continued recording them from Rome until 26 July 1943, the day after the coup that deposed Mussolini. Between this two and a half year period there occurred an unexplained gap in the talks (26 July 1942 to 18 February 1943) ) $^{23}$ and a brief respite after American entry into the war in December 1941. As to how he actually sounded, one Pound biographer describes the broadcasts this way:

Occasionally in the talk he makes a slight slip and corrects himself; often it is hard to distingu ish the names he is citing; but in general it is a masterly performance. The voice is clearly pitched-the absurdly rolled i's help to throw the words across the poor-quality short-wave transmission, so that he comes over far better than the professional announcer-and the folksy manner is perfectly attuned to the style of the "fireside chat." Some of his listeners in the USA were astonished by the whole act, observing that the accents adopted were simply stage-American: 
"if Yankee," writes Charles Norman, "more nasal than anything ever heard north of Boston, if western, more 'folksy' and drawling than anything ever heard west of the Mississippi." 24

The most striking aspect of Pound's "propaganda" is his nearly complete disregard for the listener's ability to understand it. Given this disregard, the broadcasts defy attempts and hence, the first three themes to be examined Pound's understanding of economics, his anti-Semitism, and his fervent loyalty to Mussolini and the Axis powers generally-do not play as great a part in the broadcasts as the fourth "theme," which is best described as whatever else came to his mind. In his broadcasts Pound never contradicted or challenged the Government policy, yet he made little attempt to follow it. The Social Credit economics put forth were neither adopted nor advocated by the Mussolini régime. And the government's anti-Semitic policies (which did not come to Italy until the alliance with Germany) were not nearly as strict or systematic as those found in Germanoccupied Europe-in fact, Italian-occupied areas of Croatia, France, and Greece became havens for Jewish refugees. 25 The assortment of other subjects Pound dealt with in the broadcasts were also largely irrelevant to the Fascist cause. Pound's interests and the interests of the Italian propagandists coincided only in mutual fidelity to the Duce and a desire to keep Americans out of the war when they were out, and to get them out once they had come in.

In an autobiographical skerch found in his Selected Poems, Pound wrote: "1918 began investigation of causes of war, to oppose same." This piece was an economic investigation, inspired by the originator of Social Credit theory, Major C. H. Douglas. The Great War served to reveal, both to economists and the average person, just what a country's economy could do in rime of crisis. ${ }^{26}$ The British wartime economy was particularly successful in supplying the war effort, and to many government intervention in the economy had proven itself. What the war also demonstrated 
was the arbitrary nature of money, best illustrated by Bricain's removal of the pound from the gold standard during the war, and the return to gold after. The definition of money seemed to be changing, and it was not certain just what the new definition would be. ${ }^{27}$

Part of this redefinition of money was a redefinition of credit. Douglas, borrowing from A. R. Orage (another economic thinker with whom Pound had contact), argued that there is a difference between "financial" credit and "real" credit, the former being represented in monetary terms, the latter in terms of the tools of production. ${ }^{28}$ Indeed, Douglas argued that credit had a social base, hence Social Credit. This credit could be taken out of the hands of bankers and returned to the community, its source. As Pound wrote, "the State should lend, not borrow ... in this respect, as in others, the Capicalist usurps the function of the State." ${ }^{29}$ Douglas believed that the war and the money shortages that followed it were caused by the manipulations of international financiers at the expense of the community. Usury, as these manipulations amounted to (in Pound's mind if not in the rhetoric of Douglas himself), could be ended by the distribution of national dividends. ${ }^{30}$ Pound's reading of Douglas led him to believe that usury was the source of all evil, decaying the arts and ruining human values. Summarizing Pound's beliefs, Heymann writes that the "very existence of 'the palsied shadow of usura' [as he called usury] could be traced to the poor organisation of distribution: capital was stagnating in the banks; the consumer lacked purchasing power; monopolies chrived; and credit was accorded to specific individuals and interest charged on it so that banks and lending institutions were creating money 'ex nibil.'"31

Economic considerations such as these dominated Pound's thought throughout the 1930s, and it is not surprising that so many of the broadcasts deal with the subject. Often he criticised his listeners for not knowing enough about economics and the nature of money itself. The Soviet experiment particularly intrigued him because in the Soviet 
Union the significance of economic forces was not underestimated. In a talk discussing Stalin and the Soviet régime, he declared:

Nobody on the Axis side denies that Marx discovered several genuine faults in the usury system ...

Sure Stalin approves of Marx and Engels wantin' to take ECONOMIC, political, cultural and organisational measures. And seein' as he put 'em in that order, you would expect me to fall for it?

ECONOMIC first .... So FEW people seem able to grasp simple economies without ... about three centuries delay.

Threecenturies, to get people to understand anything about anything havin' to do with money. ${ }^{32}$

In another speech, Pound inverted Marxist formulations to fit the Douglasite understanding of economics:

Captial does not come exclusively from labor. Not one man in a hundred EVEN in Europe has digested that truth and its implications. But what happens when a man who is living on the part of capital that does NOT come from labor first finds out what he is doin'? He gets scared as hell. He starts trying to conceal the cause of his privilege. He starts the class war; class war does NOT come from the bottom. The man who is doing an honest day's work feels his strength. He feels the justice of drawin' his pay. And until he's nearly starved, until he is worried to death by fear of losin' his job, you cannot get him to DO anything at all about what is taken off him. Nothing is rarer than a peasant revolt. ${ }^{33}$

This statement is perhaps the most coherent of Pound's economic beliefs to be broadcasted. 
Elsewhere, after Pearl Harbour, Pound attacks Americans for going to war "for a false accountancy system":

You ought not to be at war against Italy .... You ought to go down on your knees and thank God for Italy, thank God an Italian ... showed a way to git you out of the hell made by a false accountancy system ....

All purchasin' power does NoT come from labor, not in the world as you have known it ....

You are at war to conceal the fact that a lot of purchasing power, a lot of capital comes from a hoax. Damn the hoax. But don't go out and die for just bein' idiots. Or for your tolerance of being run and ruled over by dumheads who are pushed on by shysters. ${ }^{34}$

The theme of "false accountancy" recurs in the broadcasts, although rarely so coherently. Generally, Pound's references to economics are brief and obscure. Sometimes they come in the form of simple name-dropping, Douglas and Gesell (a German Social Creditor) being commonly referred to, usually without any clear explanation of who they are. Most frequently, Pound's economic "arguments" came in the form of threats for the country's financial future:

Debt is the prelude to slavery. And you are now, I 'spose, arrived at the intermezzo. America WAS promises. America today is largely, shall we say, promissory notes that simply can NOT be honored .... Am I to believe that you no longer have complete liberty to eat and to use automobiles? Some of the reports from the U.S.A. seem exaggerated; but in a country that swallowed Morgenthau's reports of the goings on of the American treasury: what CAN be exaggerated?

Without freedom from DEBT, there is NO rotal freedom .... 35

Savings. Another red herring. War savings. Illusion of savings! Saving tickets for something that isn't there. Theatre tickets for a show that 
never comes off, for a play that never opens? That is another hoax..$^{36}$

What unites nearly all Pound's references to economics in the radio talks is that they do nor easily stand on their own; without some prior understanding of Social Credit theories (and Pound's personal biases), listeners must have had great difficulty making sense of them.

Anti-Semitism, the second prevalent theme of the broadcasts, may have helped some listeners "understand"in an invidious way - the first. The international banking conspiracy in which Pound believed, found its perfect straw man in the Jew, against whom such bigoted accusations have been levelled throughout European history. Pound's talk of "real credit" and "capital divorced from labor" must have been difficult to digest in the span of a quickly-read, poorlytransmitted seven minute radio speech, but the line "Franklin Delano Jewsfeld" is immediately understood: it suggests treason, profiteering, and the enemy within. It is at the visceral level that anti-Semitic discourse aims, and Pound's case was no exception.

Pound's anti-Semitism has been the focus of much debate in intellectual circles, where admirers of his poetic achievement have felt compelled to address his bigotry, expressed particularly in the war broadcasts. The many questions this discussion has raised-can the artist be separated from his work? is prejudiced art still art? is the artist responsible to society? only to give a few-are beyond the issue at hand. It is useful to know, however, that there is no consensus as to when and why his anti-Semitism began. Flory places these tendencies as early as the nineteen-teens and suggests that Pound's small town environment is to blame. ${ }^{37}$ Casillo sees Pound's anti-Semitism as a four-step process starting as a common Midwest prejudice in his youth and culminating in the radio broadcasts. Redman suggests that his "overt and virulent" anti-Semitism coincides with the beginning of the war and he comes surprisingly close to blaming it on the lack of a good library in the proximity. ${ }^{38}$ Yet another opinion, in the Southern Economic Journah 
contains this original (and ridiculous) argument: "it was Pound's economic errors that led this century's foremost poet into anti-Semitism." 39

These conflicting opinions are partly a product of Pound's own ambivalence towards Jews, an ambivalence manifest in the broadcasts. While he was often vicious and always insulting, he frequently pointed out exceptions, qualifications, and distinctions that seem to be intended to mitigate the fervour of his hatred. The radio talks reveal a tension between Pound's passionate belief in an international, usury-based Jewish conspiracy, and his unwillingness to apply these judgments and prejudices to the average Jewish person.

Pound's belief in a Jewish financial conspiracy is best conveyed in his own words:

One kind of shyster succeeds another: shyster penetrates ANY organization, church or state for the sake of livin' on the Purchasing Power that DON'T come from labor. Shyster joins EVERY new movement so as to be there when it gets big and to be at the exploitin' position. [broadcast, 10 July 1942]

Just which of you is free from Jewish influence? Just which political and business groups are free from Jew influence, from Jew control? [broadcast, 19 March 1943]

Every country where these swine have been allowed to set up a rule within a rule, has been rotted .... The forces that put that utterly utter Morgenthau into the treasury will do the same to the us unless stopped .... Four years more rot ... [letter, 18 June 1940, to American Senator Burton K. Wheeler (Dem.)]

England is to be a Jew-owned deer park with tearooms. [broadcast, 8 March 1942]

The enemy is Das Leihkapital, international, wandering Loan Capital .... The big Jew is so bound up with this Leihkapital that no one is able to unscramble that omelet. It would be 
better for you to retire to Darbyshire and defy New Jerusalem, better for you to retire to Gloucester and find one spot that is England than to go on fighting for Jewry and ignoring the process.

It is an outrage that any clean lad from the country ... should be expected to die for Victor Sassoon .... [broadcast, 15 March 1942] I ask you WHY WAS CHRIST CRLCIFIED? He was crucified for trying to bust a racket. [broadcast, 4 May 1942]

These sorts of accusations are hardly new, although they bear Pound's distinct imprint. Norman Cohn, in his book Warrant for Genocide, argues that the myth of the Jewish world-conspiracy is a modern adaptation of older forms of anti-Semitism that ascribe demonic qualities to Jews. Myths of a secret Jewish government date from before the Reconquesta, and had been invoked by Pound's time to explain Manicheeism, Freemasonry, the French Revolution, and numerous other aspects of European history. ${ }^{40}$ The myth fits very comfortably into Pound's economic beliefs, the paranoia of which does not seem complete without some control group at the head. Pound believed that the war was attributable to the Jewish conspiracy, but he never clearly explained what the Jews gained from it. Nowhere does he describe the war as a fight for Jewish survival against the Nazis; nowhere in the broadcasts does he even mention the Final Solution, about which he claimed after the war to have known nothing. ${ }^{41}$ The conspiracy's motive was clearly world domination, but how the war was to bring this about Pound did not explain.

Pound believed that the Jews achieved one part of world domination, domination of the American government, before the war began. He argued ad nauseam in the broadcasts that Jewish advisors, particularly Morgenthau (Secretary of the Treasury) and Baruch (Us businessman and advisor), completely controlled the President. Pound's comments on the President and his contacts with the Jewish conspiracy are 
among the most inflammatory of the broadcasts. Roosevelt appears under the names Jewsfeld, Finkelstein, Roosenstein, Rosenfeld, Frankfurter, etc. and is described as possessing "a weakness of mind" 42 qualifying him for an insane asylum. ${ }^{43}$ Pound once told his audience, "Had you had the sense to eliminare Roosevelt and his Jews or the Jews and their Mr Roosevelt at the last election, you would not now be at war." 44

Pound's attirude toward Jews is not as clear as all this would suggest, however. He is often at pains in the broadcasts to distinguish between "Big Jews" and "Little Jews," the former being conspirators and the latter as much their victims as Pound himself.

Don't go for the poor Jews. Don't pick on the amhaarez. Look into the system.

In fact the lone Jew is subject of study. He seems a good fellow, but is he in some way cur off from the organization? Has he declined to kiss the magic rod ... is he in exile ... is that why he has apparently no more luck than the goyim? ${ }^{245}$

Pound's broadcasts also contain an element of what Redman calls anti-Semitic Zionism, in which he suggested that the Jews be sold Australia, or a part of Poland, or Bolivia. Such suggestions may seem ridiculous (if not insulting), but Flory argues that these abortive attempts to qualify and justify his anti-Semitism are evidence of "the continuing influence over him of his sense of moral responsibility. "46 Whether these observations amount to splitting hairs one must decide for oneself. There is, however, an undeniable tension between the sweeping generalisations Pound makes about Jews and the time he spends distinguishing between "the sixty Kikes who started the war" and the "small Jews" that would be hurt by a pogrom, which he advises against. ${ }^{47}$

The third prevailing theme of the broadcasts is not nearly as complicated as either Pound's economics or his anti-Semitism: his hero-worship of Mussolini and his 
idealisation of the Axis cause. This sort of propaganda is more what one would expect from Rome Radio during the war. Pound sings the praises of Fascist Italy in his broadcasts as he did in Jefferson andlor Mussolini, only now also includes Hitler-whom, according to Yeats, he once referred to as "that hysterical imicator" of Mussolini ${ }^{48}$ —in his rhetoric. A sample of his comments suffices:

Every hour that you go on with this war is an hour lost to you and your children. And every sane act you commit is committed in HOMAGE to Mussolini and Hitler. Every reform, every lurch toward the just price, toward the control of a market, is an act of HOMAGE to Mussolini and Hitler. THEY are your leaders, however much you think you are conducted by Roosevelt or told up by Churchill. You FOLLowMussolini and Hitler in EVERY CONSTRUCTIVE act of your government. [26 May, 1942]

And the pathological brainstorm in the White House after years of robbing the country, dipping into the Treasury, years of frothing at the mouth about Mussolini and Hitler, in mid January comes out with a discourse and EVERY single item in it that has a trace of sanity is IMITATED from Mussolini or Hitler. [26 February, 1942]

Mussolini stands for social justice, for breaking the usurer's bondage ... [31 May 1942]

I have noticed DIscrepancies... I heard Mussolini say "WE need years of peace to get on with our internal affairs." And I have seen it reported next day as a war speech.

Also Mussolini talking about the fight to grow enough wheat to feed Italy as being the kind of fight he prefers. Well, that was the effort that brought out American hostility all right enough. [6 March 1942]

As is evident here, Pound projected his personal fantasies and prejudices on the leaders he followed. Mussolini did nor care about "the usurer's bondage" nor did he or Hitler pay 
much attention to "the just price" or the control of markets-except to meet the military demands of the war. Economic reform was not the slogan of right-wing revolutionaries in Italy, nor in Germany, but Pound seemed not to have noticed, or not to have cared. Pound adopted the Axis powers as a vehicle for his own personality, and ascribed to them his own beliefs.

The three themes discussed above are not as pervasive in Pound's war broadcasts as the "anti-theme" of personal attacks, literary and artistic allusions, discussions of Confucian philosophy, lessons in American history (à la Ezra, of course), and responses to things Pound read or heard in the news media. Such discussions are often difficult to follow, and sometimes utterly incomprehensible:

And $\mathrm{Mr}$ Fouquet, and pop Quackenbush, all that generation that remembered the Civil War. All gone with the ash barrels. Think of swell ballroom, right where my Great Uncle used to keep his bunch of bananas, and I used to play chequers with him; my old Great Aunt's black man of general all work, or rather any work, some work, that he used to dodge to play chequers on top of the apple barrel, before the days of the Windsor fire, Two Hotels, Windsor and Buckingham, ornament of Fifth Avenue, back before you kids remember. ${ }^{49}$

We might include in this "anti-theme" what Pound did not say. He never spoke directly to Allied troops. He only rarely mentioned the actual events of the war, and entirely ignored Allied victories and defeats. As one of his biographers writes, "the conflict seemed to exist for him on a purely intellectual plane." 50

The question that arises from this sort of material is, what does it have to do with the war, or with the Fascist cause? We have seen that Pound's underscanding of Fascist policy is obscured by his own prejudices and paranoia. This 
fact is particularly evident in a passage from Pound's 1944 work L'America, Roosevelt e le Cause della Guerra Presente, in which he argues that the war
was not caused by any caprice on Mussolni's part, nor on Hitler's. This war is part of the secular war between usurers and peasants, between the usurocracy and whomever does an honest day's work with his own brain or hands."

No one else in the world at the time accounted for the war in this way. Pound is not speaking from a prefabricated ideological position, but from his own, inimitable personality. Thus, he cannor belumped in with other radio propagandists, nor with other high-profile Fascist intellectuals like Wyndham Lewis and Pierre Drieu la Rochelle. Ultimately, Pound's radio broadcasts, and for that matter all his documented "thought" on Fascism, are rooted in his own opinions rather than in the doctrines of Mussolini or Hitler. Pound was propounding his own political and economic views on the pretext of talking about Fascism. Spreading his economic beliefs, revealing the Jewish conspiracy, and telling America what he perceived to be the truth about Mussolini and the Axis were his sincere morives, but only the latter coincided with the policies and goals of the Italian government, just barely. Flory has suggested that Pound sometimes seemed to be calking to himself; one might add that he seemed sometimes to be calking for himself. ${ }^{52}$

\section{IV}

Very few people heard Pound's broadcasts, or at least paid any attention to them. "As propaganda, Pound's broadcasts were a flat failure," John Diggins writes, ${ }^{53}$ adding that "the messages had no influence on Allied morale." They caused some stir among American and British intellectuals, but they do not seem to have caught the attention of the average person-this in spite of the showmanship of Pound's delivery. ${ }^{54} \mathrm{He}$ recognised the problem of attracting an 
audience and suggested ways to liven up the programme. For example, he asked his producers to begin each talk with a fanfare and the announcement: "Dr Pound is approaching the microphone!" The request was refused."s $\mathrm{He}$ also penned this curious advertisement for one of the broadcasts:

Today at 4:15 p.m. (EST), Ezra Pound, the expatriate American poet who lives in Italy and loves it, discusses on the ltalian short-wave radio "The Limits of Human Understanding." Democratically speaking, he's a stinker, but academically he is a fine example of an American gone totalitarian."

All Pound's attempts to attract larger audiences ignored the real obstacle to achieving a substantial listening audience: Pound himself. The message of his broadcasts was so clouded by his non-linear, nonsensical style that most of the speeches were difficult if not impossible to follow. Stock notes that Pound himself mentioned the difficulty he sometimes had to make himself understood. "I lose my thread some times," he told his audience of 8 March 1942, "so much that I can't count on anyone's knowing. Thread, as they call it, of discourse."

It was in March 1941 that Pound's unorthodox style and subject matter first caught the attention of Italian Government officials. They feared that the many allegations and insults Pound directed toward America and its government were inappropriate given that the two countries were not yet at war. Italian military intelligence reported to the radio staff that one of their officers had spoken with the American ambassador, and both had agreed that Pound should be removed. ${ }^{58}$ Villari stepped in again, writing:

There is no doubt in my mind that Ezra Pound is insane! He is a pleasant enough madman and he is certainly a friend of lealy, but in the course of two interviews I recently had with him, I 
heard criticism, circumspection, accusations, etc. that have rather alarmed me .... It is advisable that such things be stopped from the start.

But little came of such comments. Pound was asked to talk less about politics and more about literature, but he was "furious at the idea that ANybody in the office would have thought they knew enough to amend my Ezment" and made no changes. After this incident, he seems to have been either tolerated or ignored by government authorities. Mussolini himself knew nothing about him. ${ }^{59}$

The American government was not so complacent. In July 1941 the State Department limited Pound's passport for return to the United States only. A later State Department memorandum called him as a "pseudo-American."60 The us never softened its position, and on 26 July 1943 Pound was indicted in absentia for treason. The indictment took him by surprise, he said seventeen years later. ${ }^{(1)}$ He apparencly believed that the announcement preceding each of his broadcasts after America entered the war ("It is understood that [Pound] will not be asked to say anything whatsoever that goes against his conscience, or anything incompatible with his duties as a citizen of the United States of America") would suffice to protect him. It did not. Almost two years later, in May 1945, us occupying forces arrested him. By the year's end he was declared insane and mentally unfit for trial. He was removed to St. Elizabeths Hospital, Washington, where he spent twelve years. ${ }^{62}$

In Hugh Selwyn Mauberley, Pound, alluding to a passage in Ovid, writes: "Mouths biting empry air, / The still stone dogs, / Caught in metamorphosis, were / Left him as epilogues." Twenty years later he too would be a mouth biting empty air, reading agitated and incoherent scripts over short-wave radio to a seemingly nonexistent audience. He proved to be an ineffectual propagandist- "No HawHaw He" as Time magazine mistakenly (but correctly, in hindsight) reported in January 1942, when it was believed that he had "retired to Rapallo to continue his study of 
Ezra Pound's Radio Broadcasts 69

Chinese philosophy." ${ }^{33}$ He would have been better off to have done so, for his two years of broadcasting landed him in an asylum, damaged his reputation, and did nothing to promote the Axis cause. 


\section{NOTES}

' See Richard F.llman. 'He Do the Police in Different Voices' in a long the riverun: selected essays (New York, 1989)

'See Hugh Kenner, The Pound Era (Berkeley and Los Angeles, 1971)

"Sec introduction to Ezra Pound, "Fzm Pound Spenking "Radio Speeches of World War II, ed. Leonard W. Doob (Westport, 1978), xiv.

"Denis Donoghuc, "Pound's Book of Beasts" in The New York Review of Books 39,9 (2 June 1988), 14-16

'An excellent clucidation of that work is in Humphrey Carpenter, $A$ Serious Character: The Life of Ezra Pound (Boston, 1988), 493-7.

"Carpenter, A Serious Character, 458. When not otherwise noted. hiographical information about Pound comes from this source.

'Tim Redman, Ezra Pound and Italian Fascism (Cambridge, 1991), 76

"Carpenter, A Serious Character. 488

" lbid., 490

"Redman, Ezra Pound and Italian Fascism. 95

"Ezra Pound, Jefferson and/or Mussolini (New York, 1936), 11

1: Ibid., ii

"Carpenter, A Serious Charcter, 499

14 William M. Chace. The Political ldentities of Ezra Pound and T.S.

Eliot (Stanford. 1973), 64

"Pound. Jefferson and/or Mussolini, 12

"Ibid., 98

17 Chace, The Political Identities of Ezra Pound and T.S. Eliot, 65.

is Pound. Jefferson and/or Mussolini, 66

" Carpenter, A Serious Charter, 567

in Ihid.

"C. David Heymann, Lzra Pound: The Last Rouer(New York, 1976).

92

${ }^{22}$ Pound in Carpenter. A Serious Charcter, 568

$\because$ Redman. Ezra Pound and linlian liascism. 221

${ }^{24}$ Carpenter, A Serious Charcter, 589

"Meir Michaclis in Wendy Stallard Iory. The American lizra Paund (New Haven, 1989), 137-8

${ }^{26}$ Redman, Liza Pound and Italian Fascism, 52

27 Ihid.

${ }^{28}$ Jbid., 54

29 Pound in Redman, Fzra Pound and Italian Fascism, 54 5

"Heymann. Ezra Paund. 32

"lhid., 34

"Pound. "Ezra Pound Speaking." 12

"Ibid., 195

4 [bid.. 21.3 
"s Ibid., 227

3. Ibid., 302-3

${ }^{37}$ See Flory. The American Ezra Pound, 136.

${ }^{38}$ Redman, Ezra Pound and Italian Fascism, 194 and 202

"9enneth G. Elzinga and William Breit, "Ezra Pound and the GNP" in Southern Economic Journal 46,3 (January, 1980). 9104. Italics mine. 4" See chapter one of Norman Cohn, Warrant for Genocide: the Myth of the Jewish World-Conspiracy and the Protocals of the Elders of Zion. (London, 1967).

4. Carpenter, A Serious Charcter, 612

42 Pound, "Ezra Pound Spenking." 27

"Ibid., 84

"Ihid., 105

"Ibid. 330

${ }^{46}$ See Flory. The American Ezra Pound, 131-155.

1" Ibid. The full quotation reads: "Don't start a pogrom. That is, not an old style killing of small jews. That system is no good whatsoever. Of course if some man had a stroke of genius and could start a pogrom up AT THE top, there might he something to say for it." The last line has often been misinterpreted as advocating the sort of centrally-planned extermination "up at the top" that Hitler masterminded. In context, ] take it to mean "up at the top of the world conspiracy" i.c. a pogrom limited to "the sixty Kikes who started the war." Still not a pleasant suggestion, but the distincrion is significant.

${ }^{48}$ Carpenter. A Serious Character. 503

19 Pound, "Ezra Pound Speaking, " 99

so Carpenter, A Serious Character, 617

"Pound in Alistair Hamilton. The Appeal of Fascism (New York, 1973). 326. Jealics are mine.

52 Flory. The American Eara Pound, 140

"John P. Diggins. Mussolini and Fascism: the View from America (Princeton, 1972), 438

"There is a curious essay that appeared in 1968 that would seem to partially refute this claim. The article. "Ezra Pound and my Father," eells the story of a teenage poetry enthusiast whose father becomes enthraled with Pound's broadcasts. Whether the story is authentic is impossible to know. See Dannic Abse. "Ezra Pound and my Father"

in Twentiesh Century 176.1036 (1968), 42-4.

"S Carpenter. A Serious Charcter. 592

" Pound in Redman. Ezrn Pound and Italian Fascism, 209

"Stock, l.ife of Ezrn Pound, 394; Pound, "Ezra Paund Speaking, " 57

"Carpenter. A Serious Character, 585

(9) Ibid., 597

(n) Stock, life of Ezra Pound. 391

6 Carpenter. A Serious Character. 623 


\section{Past Imperfect}

a. Julien Cornell. The Trial af Ezrn Paund: A Documented Account of the Treason Case by the Defendant's Lawyer (New York, 1966), 36-8

${ }^{63}$ Carpenter, A Serious Character, 6017-8 